UDC 616.329-002-02: 616.33-008.17]-06: [616.12-008.331.1-02: 575.174.015.3

DOI: $10.21668 /$ health.risk/2020.1.14.eng

\title{
TNF GENE POLYMORPHISM AS A RISK FACTOR THAT CAN CAUSE ARTERIAL HYPERTENSION IN PATIENTS SUFFERING FROM GASTROESOPHAGEAL REFLUX DISEASE
}

\author{
O.V. Khlynova ${ }^{1}$, E.A. Shishkina ${ }^{1}$, V. Sakhena ${ }^{1}$, A.V. Krivtsov ${ }^{2}$, \\ G.N. Spasenkov ${ }^{3}$, N.I. Abgaryan ${ }^{3}$
}

${ }^{1}$ Perm State Medical University named after Academician E.A. Wagner, 26 Petropavlovskaya Str., Perm, 614000, Russian Federation

${ }^{2}$ Federal Scientific Center for Medical and Preventive Health Risk Management Technologies, 82 Monastyrskaya Str., Perm, 614045, Russian Federation

${ }^{3}$ Cardiologic Clinic, 8 Sibirskaya Str., Perm, 614002, Russian Federation

Comorbidity of arterial hypertension (AH) and gastroesophageal reflux disease (GERD) is widely spread (from $20.6 \%$ to $29 \%$ ); despite that fact, risk factors that can cause AH in patients suffering from GERD have still not been examined completely. Experts are discussing a role played by anti-inflammation cytokine of tumor necrosis factor alpha (TNF $\alpha)$ both in AH occurrence and GERD pathogenesis as it is its activity that is to a great extent determined by a patient having certain alleles of tumor necrosis factor (TNF) gene. Therefore, it seems vital to study TNF gene G308A polymorphism in patients with combined AH and GERD.

Our research goal was to study frequency and variants of TNF gene G308A polymorphism relations with AH risk and AH phenotypic peculiarities in patients suffering from GERD.

We examined 58 people who had AH (29 patients with isolated AH, average age being 53 [46; 62], and 29 patients with combined AH and GERD, average age being 56 [51; 59]). Patients from both groups were comparable in terms of sex, age, and examined factors of cardiovascular diseases risks. We applied allele-specific polymerase reaction with test systems produced by "Sintol" LLC (Moscow) to determine G308A (rs1800629) polymorphism of TNF gene. To assess relations between alleles and genotypes and disease risks, we calculated odds ratio (OR) with $95 \%$ confidence interval (CI).

We revealed a relation between G308A polymorph marker of TNF gene and systolic blood pressure and disorders in tolerance to dextrose among patients with comorbid AH and GERD. Patients with combined AH and GERD had unfavorable allele $A$ and $G / A$ genotype authentically more frequently (OR 5.14; $95 \% C I-1.06-24.95 ; p=0.03$, OR 6.08; $95 \% C I-$ $1.18-31.25 ; p=0.02$ accordingly).

We showed that G308A polymorphism was related to AH occurrence in patients suffering from GERD. These data confirm that endothelial dysfunction plays a significant role in AH pathogenesis among such patients.

Key words: arterial hypertension, gastroesophageal reflux disease, comorbidity, endothelial dysfunction, risk factor, genetic polymorphism, TNF gene, arterial hypertension phenotype.

Over the last decades arterial hypertension $(\mathrm{AH})$ has been a most widely spread and socially significant cardiovascular disease [1]. As per data obtained via epidemiologic research high blood pressure (BP) is registered in $39-40 \%$ population of the Russian Federation [2]. Today more and more patients with $\mathrm{AH}$ have one or more associated diseases and comorbidity and poly-morbidity tend to grow among older patients. Concomitant pathology

(c) Khlynova O.V., Shishkina E.A., Sakhena V., Krivtsov A.V., Spasenkov G.N., Abgaryan N.I., 2020

Olga V. Khlynova - Corresponding Member of the RAS, Doctor of Medical Sciences, Professor, Head of the Hospital Therapy Department (e-mail: olgakhlynova@mail.ru; tel.: +7 (342) 239-31-88; ORCID: https://orcid.org/0000-0003-4860-0112).

Ekaterina A. Shishkina - Candidate of Medical Sciences, Assistants at the Hospital Therapy Department (e-mail: doctor.shishkina@yandex.ru; tel.: +7 (342) 239-31-88; ORCID: http: //orcid.org/0000-0001-6965-7869).

Vikas Sakhena - Seeker for an academic degree at the Hospital Therapy Department (not taking post-graduate course) (e-mail: saxena.vikas@yandex.ru; tel.: +7 (342) 239-31-88; ORCID: https://orcid.org/0000-0002-7175-2264).

Aleksandr V. Krivtsov - Candidate of Medical Sciences, Head of the Immunogenetics Laboratory (e-mail: Krivtsov@fcrisk.ru; tel.:+7 (342) 236-86-99; ORCID: http: //orcid.org/0000-0001-7986-0326).

Grigorii N. Spasenkov - Head of the Cardiology and Prevention Department (e-mail: Spy5502@mail.ru; tel.: +7 (342) 216-99-09; ORCID: http: //orcid.org/0000-0003-1085-5814).

Natalya I. Abgaryan - Cardiologist at the Cardiology Department (e-mail: docnatashka01@mail.ru; tel.: +7 (342) 216-99-09; ORCID: http: //orcid.org/0000-0001-6946-54645). 
determines variability of clinical symptoms that a basic pathology might have, influences prediction and life quality of a patient and in some cases makes it necessary to change therapeutic tactics in treating a patient [3]. Cases in which $\mathrm{AH}$ combines with pancreatic diabetes, ischemic heart disease, or chronic kidney failure have been studied in detail and given pathogenetic substantiation. But still, an issue related to comorbid pathology regarding $\mathrm{AH}$ and other socially significant diseases, gastric ones in particular, is becoming truly vital at the moment.

Gastroesophageal reflux disease (GERD) is among the most frequent pathologies occurring in the gastroduodenal area; it is widely spread (up to $60 \%$ ) among adult population in the RF. Results of a multicenter trial «Epidemiology of Gastroesophageal Reflux Disease in Russia» [4] indicate that $61.7 \%$ men and $63.6 \%$ women in Russian have heartburn that is the primary GERD symptom. According to foreign researchers, AH prevalence among patients suffering from GERD varies from $20.6 \%$ to $29 \%$ [5].

The above data allow considering $\mathrm{AH}$ and GERD comorbidity being quite possible; frequent combination of the said nosologies allows assuming there is a specific pathogenetic regularity in their associated clinical course.

Apart from traditional risk factors that cause AH and GERD occurrence and development, a lot of attention is given to a pathogenetic role played by inflammatory mediators; another issue under discussion is a relation between anti-inflammatory cytokines and endothelial dysfunction occurrence together with vascular walls becoming more rigid $[6,7]$.

Tumor necrosis factor alpha $(\mathrm{TNF} \alpha)$ is a multifunctional anti-inflammatory cytokine that participates in regulating a wide range of biological processes; its activity to a great extent depends on carrying specific alleles of tumor necrosis factor $(T N F)$ gene.

Therefore, TNF gene can be examined among candidate genes that can take part in AH occurrence among patients with GERD; it can be interesting from a practical point of view to examine polymorphism of the said gene in patients who suffer from combined $\mathrm{AH}$ and GERD.

All the above mentioned determined the research goal that was to examine prevalence and variants of a relation between G308A polymorphism in $T N F$ gene and a risk of $\mathrm{AH}$ occurrence among patients suffering from GERD as well as phenotypic peculiarities of the disease.

Data and methods. Overall, 58 patients with AH took part in the research; 29 patients (the test group) also suffered from GERD. The reference group was made up of 29 patients who had only AH. All the patients were comparable in terms of their sex, age, and duration of the main disease. The examination was performed in the Cardiology and Prevention Department of the Regional Cardiologic Clinic (Perm). All the patients gave their written informed consent to take part in the examination. The research was also granted permission by the local ethical committee of the E.A. Vagner's Perm State Medical University (Protocol no. 8 , October 02,2018 ).

There were certain criteria for a patient to be excluded from the research; they were $\mathrm{AH}$ being only a secondary disease; cardiac infarction in a case history or exertion angina higher than II category; pancreatic diabetes; chronic kidney failure higher than $\mathrm{C} 3 \mathrm{a}$ stage; hepatic failure; chronic heart failure higher than IIA category as per New York Cardiology Associates classification; malignant neoplasms of any localization; absence of a written informed consent to take part in the research.

$\mathrm{AH}$ was diagnosed according to recommendations on AH given by the Russian Medical Society for Arterial Hypertension (the $4^{\text {th }}$ edition) [8]. To initially screen GERD, we applied GerdQ questionnaire (method sensitivity is $91.7 \%$; method specificity, $65.4 \%$ ) which allowed diagnosing GERD during an initial contact with a patient [9]. Later on GERD was confirmed according to the up-todate clinical guidelines given by the Russian gastroenterological association [10].

Laboratory and instrumental examination of patients was performed in conformity with the standard for providing medical and sani- 
tary aid to patients with primary AH (supplement to the RF Public Healthcare Ministry Order No. 708n issued on November 09, 2012). Additionally all the patients had their blood pressure monitored for 24 hours uninterruptedly with devices produced by BPLab (Russia) prior to any anti-hypertension therapy was prescribed.

A smear from a cheek mucosa was taken from each participant in the examination; it was done with a dry sterile probe with a cotton pellet. Then, allele-specific polymerase chain reaction with the use of test systems produced by "Syntol" LLC (Moscow) was applied to determine G 308A (rs1800629) polymorphism in tumor necrosis factor (TNF) gene.

The results were statistically processed with certified computer software. All the obtained data were given as $\mathrm{Me}(25 ; 75)$ where Me was a median, 25 and 75 were $25^{\text {th }}$ and $75^{\text {th }}$ percentiles. Non-parametric values were compared with Mann-Whitney test. To statistically analyze how frequencies of alleles and genotypes were distributed, we applied contingency tables with calculating $\chi^{2}$. Discrepancies were considered authentic at $\mathrm{p}<0.05$. To assess a relation between alleles and genotypes and a risk of the diseases occurrence, we calculated odds ratio (OR) with $95 \%$ confidence interval (CI). Conformity of genotypes frequencies distribution with Hardy-Weinberg principle was determined with a specific software package called "Calculator for calculating statistics in case-control studies".

Results and discussion. It was a simple open comparative study. Median age of patients from the test group was $56(51 ; 59)$; in the reference group, $53(46 ; 62)(\mathrm{p}=0.392)$. Men prevailed in both groups $(82 \%$ and $79 \%$ accordingly). Patients were comparable as per their body mass index (BMI), smoking status, and AH duration $(p=0.733)$. Patients with the II stage increase in blood pressure prevailed in both groups $(51.21 \%$ among patients with $\mathrm{AH}$ only and $55.55 \%$ among patients with $\mathrm{AH}$ and GERD combined), II stage AH (56.09\% and $59.25 \%)$, the $3^{\text {rd }}$ risk degree $(48.14 \%$ and $43.9 \%$ ) accordingly. Having examined G308A polymorphism, we determined that $\mathrm{G} / \mathrm{G}$ and G/A genotypes prevalence amounted to $77.94 \%$ and $22.05 \%$ accordingly among patients with $\mathrm{AH}$, frequencies distribution didn't deviate from Hardy-Weinberg principle $\left(\chi^{2}=0.79, p=0.37\right)$. These results are well in line with data obtained by other researchers and don't have any significant discrepancies from distribution of genotypes in most European populations $[11,12]$.

Table contains data on frequency of G308A polymorph marker genotypes in $T N F$ gene among patients suffering from $\mathrm{AH}$ only and AH combined with GERD.

Table

Distribution of -308GA (rs1800629) polymorph marker frequent alleles and genotypes in $T N F$ gene among patients from the test and reference group (multiplicative and additive inheritance model) chi-square test, $\mathrm{df}=1$

\begin{tabular}{|c|c|c|c|c|c|c|}
\hline \multirow{2}{*}{$\begin{array}{c}\text { Tumor necrosis factor } \\
\text { alpha gene }(T N F)\end{array}$} & \multicolumn{2}{|c|}{$\begin{array}{c}\text { Distribution of alleles and genotypes } \\
\text { frequencies }\end{array}$} & \multirow{2}{*}{$\chi^{2}$} & \multicolumn{3}{|c|}{ OR } \\
\cline { 2 - 3 } Alleles and genotypes & $\begin{array}{c}\text { The test group } \\
\text { (AH and GERD) } \mathrm{n}=29\end{array}$ & $\begin{array}{c}\text { The reference } \\
\text { group }(\mathrm{AH}) \mathrm{n}=29\end{array}$ & & & & \multicolumn{2}{|c|}{ value } & CI \\
\hline $\mathrm{G}$ & $49(84.5 \%)$ & $56(96.6 \%)$ & 4.92 & $0.03 *$ & 0.19 & $0.04-0.94$ \\
\hline $\mathrm{A}$ & $9(15.5 \%)$ & $2(3.4 \%)$ & & & 5.14 & $1.06-24.95$ \\
\hline $\mathrm{G} / \mathrm{G}$ & $20(69 \%)$ & $27(93.1 \%)$ & & & 0.16 & $0.03-0.85$ \\
\hline $\mathrm{G} / \mathrm{A}$ & $9(31 \%)$ & $2(6.9 \%)$ & 5.5 & $0.02 *$ & 6.08 & $1.18-31.25$ \\
\hline $\mathrm{A} / \mathrm{A}$ & 0 & 0 & & & 1.0 & $0.02-52.10$ \\
\hline
\end{tabular}

Note: $T N F$ is tumor necrosis factor alpha gene;

$\mathrm{AH}$ is arterial hypertension;

GERD is gastroesophageal reflux disease;

OR is odds ratio;

* means significance of discrepancies. 
Mutant allele A in TNF gene was determined in $15.5 \%$ cases among patients who suffered form both AH and GERD; in $3.4 \%$ cases, among patients who had $\mathrm{AH}$ only. Therefore, adverse allele A prevailed among patients with $\mathrm{AH}$ and GERD combined (OR 5.14; $95 \%$ CI 1.06-24.95; $\mathrm{p}=0.03$ ). Prevalence of G/A heterozygotes among allele A carriers was also authentically higher among patients with comorbid AH and GERD (OR 6.08; $95 \%$ CI 1.18-31.25; p=0.02) (Figure). We didn't reveal patients with A/A genotype in either group.

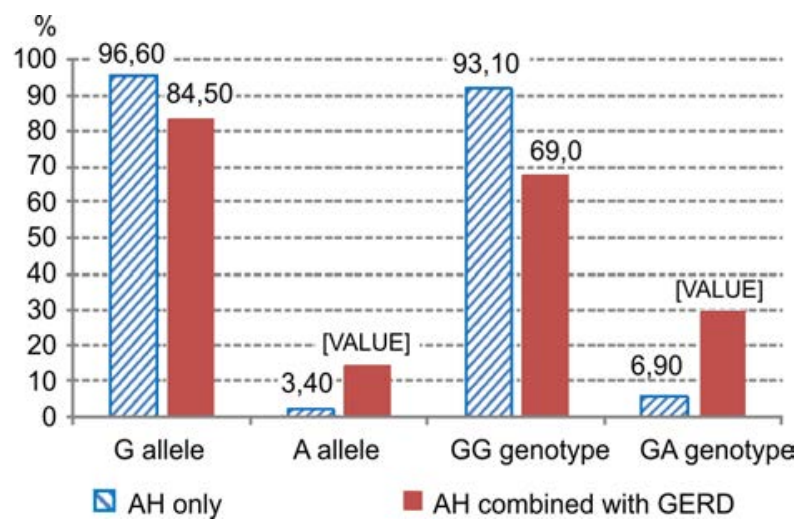

Note: $T N F$ is tumor necrosis factor alpha gene; OR is odds ratio;

* means significance of discrepancies

Figure. Frequency of G308A polymorph marker alleles and genotypes in TNF gene among patients with $\mathrm{AH}$ and $\mathrm{AH}$ and GERD combined

The next stage in our research was a search for possible relations between G308A genotype in TNF gene and clinical peculiarities and risk factors that could cause $\mathrm{AH}$ in the examined groups.

We didn't establish any relations between TNF gene G308A polymorphism and BMI, lipid metabolism, TNF and C-reactive protein contents in plasma, or echocardiographic parameters. At the same time, we revealed a relation between minor allele $\mathrm{A}$ and possible disorders in carbohydrate metabolism. Heterozygote genotype G/A in TNF gene was higher $(27.6 \%)$ among patients with combined $\mathrm{AH}$ and GERD and abnormal glycemia on an empty stomach (dextrose contents in blood plasma is $6.1-6.9 \mathrm{mmol} / \mathrm{l}$ ) than among people with normal glycemia $(6.7 \%, p=0.03)$. $\mathrm{G} / \mathrm{A}$ genotype carriers among patients with combined pathologies ran 5 times higher risk of increased dextrose contents than their counterparts with $\mathrm{G} / \mathrm{G}$ genotype (OR 5.33; $95 \%$ CI 1.02-27.76; $p=0.03)$. We didn't reveal any similar discrepancies among patients who suffered only from AH. Despite the fact that patients from both groups were comparable as per an increase in their blood pressure and prescribed medications, we revealed a relation between minor allele $\mathrm{A}$ in $T N F$ gene and a possibility of $\mathrm{AH}$ developing into severe one (as per systolic AH). A risk of systolic blood pressure rising higher than $150 \mathrm{mmHg}$ was almost 4 times higher among G/A genotype carriers than those with $\mathrm{G} / \mathrm{G}$ genotype (OR 3.92, CI 0.97-15.90; $p=0.04$ ) among patients with combined AH and GERD. We didn't reveal any similar discrepancies among patients who suffered from $\mathrm{AH}$ only.

$T N F$ gene is mapped on a shirt arm of the 6th chromosome (6r21.33) and belongs to a locus of genes in the basic histocompatibility complex. There are established relations between TNF gene polymorphism and pancreatic diabetes occurrence, insulin resistance $[13,14]$, respiratory organs diseases, atherosclerosis [15, 16], and oncologic diseases. There is also an established relation between a polymorph variant of G308A in TNF gene and an elevated risk of acute coronary syndrome and high risks of adverse coronary outcomes after a cardiac infarction [17]. Several research works dwelled on determining precisely what relation existed between G308A polymorphism and AH development. A meta-analysis that included 2,224 works [12] revealed a relation between carrying allele A of polymorph G308A variant and an elevated risk of AH occurrence (OR 1.45). The same research indicated that a relation with $\mathrm{AH}$ was 2 times stronger for AA genotype in $T N F$ gene (OR 3.454).

A role played by TNF gene polymorphism in diseases occurring in the gastroduodenal area has also been proven. Foreign researchers are now discussing a role played by G308A polymorphism in occurrence of erosive reflux-esophagitis and esophagus cancer; 
however, results obtained by them are still contradictory and require further investigation in the area $[18,19]$.

Allele variants of $T N F$ gene are known to regulate TNF expression. A role played by TNF- $\alpha$ in cardiovascular pathology occurrence is undisputable. There is evidence that TNF- $\alpha$ contents in blood plasma go up proportionate to blood pressure. There are also data in literature on a predictor role played by TNF- $\alpha$ in GERD and Barrett's esophagus development as per long-term research data [20]. It was established that when metaplasia progresses, TNF- $\alpha$ expression grows in epithelial cells in the esophagus [21].

An increase in TNF $\alpha$ contents produces an instant cytotoxic effect easing off degranulation of neutrophilic granulocytes and inducing lipid peroxidation. It results in structural integrity of endothelial cells being violated and their functions being disrupted; a decrease in vasodilators synthesis and release; an increase in endothelin-1 and angiotensinogen production. All this makes for endothelial dysfunction occurrence [22].

We didn't reveal any relations between G308A polymorphism in TNF gene and TNF- $\alpha$ activity in blood plasma in our research; it can be due to its low concentration in the examined patients $(0.085(0 ; 0.525)$ $\mathrm{pg} / \mathrm{ml}$ ). But we were the first to attempt to reveal a relation between G308A polymorphism and a risk of $\mathrm{AH}$ occurrence in patients suffering from GERD. The obtained data indicate that $\mathrm{AH}$ occurrence in patients with GERD is to a certain extent determined by a patient carrying G/A genotype in $T N F$ gene. It is quite possible to assume that endothelial dysfunction in patients with GERD occurring due to impacts exerted by G308A polymorphism can be a pathogenetic mechanism that induces $\mathrm{AH}$ in such patients. Though, we established relations between polymorphism and systolic blood pressure and carbohydrate metabolism disorders in patients with combined AH and GERD; it allows us to assume that G308A polymorphism in TNF gene influences clinical and metabolic peculiarities of $\mathrm{AH}$ in such patients.

Conclusion. Given high prevalence of comorbid AH and GERD, it is rather necessary to further search for any relations between molecular-genetic mechanisms of $\mathrm{AH}$ occurrence in patients with both pathologies combined. The results of the present work supplement already existing data on AH and GERD comorbidity and highlight a significant role played by endothelial dysfunction in pathogenesis of the said nosologies. Allele $\mathrm{A}$ in $T N F$ gene (G308A) in a form of G/A heterozygote allows considering this genotype an additional marker of specific AH phenotype occurring in patients with GERD. Genetic profile determination can be additionally applied when patients with GERD are screened in order to reveal those running elevated $\mathrm{AH}$ risks among them. The results presented in this work not only allow enhancing an insight into a genetic component in AH occurrence among patients with GERD but also give grounds for working out prevention programs aimed at reducing cardiovascular risks among patients suffering from GERD.

Funding. The research was not granted any financial support.

Conflict of interests. The authors declare there is no any conflict of interests.

\section{References}

1. Forouzanfar M.H., Liu P., Roth G.A., Ng M., Biryukov S., Marczak L., Alexander L., Estep K. [et al.]. Global Burden of Hypertension and Systolic Blood Pressureofat Least 110 to $115 \mathrm{~mm} \mathrm{Hg}, 1990$ 2015. JAMA, 2017, vol. 317, no. 2, pp. 165-182. DOI: 10.1001/jama.2016.19043

2. Boitsov S.A., Balanova Yu.A., Shal'nova S.A., Deev A.D., Artamonova G.V., Gatagonova T.M., Duplyakov D.V., Efanov A.Yu. [et al.]. Arterial hypertension among individuals of 25-64 years old: prevalence, awareness, treatment and control. By the data from ECCD. Kardiovaskulyarnaya terapiya $i$ profilaktika, 2014, vol. 13, no. 4, pp. 4-14 (in Russian).

3. Vertkin A.L., Rumyantsev M.A., Skotnikov A.S. Komorbidnost' v klinicheskoi praktike. Chast' 1 [Comorbidity in clinical practice. Part I.]. Arkhiv vnutrennei meditsiny, 2011, no. 1, pp. 16-20 (in Russian). 
4. Lazebnik L.B., Masharova A.A., Bordin D.S., Vasil'ev Yu.V., Tkachenko E.I., Abdulkhakov R.A., Butov M.A., Eremina E.Yu. [et al.]. Results of a multicenter trial «Epidemiology of Gastroesophageal Reflux Disease in Russia» (MEGRE). Terapevticheskii arkhiv, 2011, vol. 83, no. 1, pp. 45-50 (in Russian).

5. Comorbidities are Frequent in Patients with Gastroesophageal Reflux Disease in a Tertiary Health Care Hospital Article in Clinics (São Paulo, Brazil). Sci. Elo., 2009, vol. 64, no. 8, pp. 785-790. Available at: http: //www.scielo.br/scielo.php? script $=$ sci_arttext\&pid $=$ S1807-59322009000800013\&lng $=$ en\&nrm $=$ iso (29.07.2019).

6. Kusche-Vihrog K., Urbanova K., Blanqué A., Wilhelmi M., Schillers H., Kliche K., Pavenstädt H., Brand E., Oberleithner H. C-reactive protein makes human endothelium stiff and tight. Hypertension, 2011, vol. 57, no. 2, pp. 231-237. DOI: 10.1161/HYPERTENSIONAHA.110.163444

7. Babbitt D.M., Kim J.S., Forrester S.J., Brown M.D., ParkJ.Y. Effect of Interleukin-10 and laminar shear stress on endothelial nitric oxide synthase and nitric oxide in African American human umbilical vein endothelial cells. Ethnicity and Disease, 2015, vol. 25, no. 4, pp. 413-418. DOI: 10.18865/ed.25.4.413

8. Chazova I.E., Ratova L.G., Boitsov S.A., Nebieridze D.V., Karpov Yu.A., Belousov Yu.B., Volkova E.G., Galyavich A.S. [et al.]. Diagnostika i lechenie arterial'noi gipertenzii (Rekomendatsii Rossiiskogo meditsinskogo obshchestva po arterial'noi gipertonii i Vserossiiskogo nauchnogo obshchestva kardiologov) [Arterial hypertension: diagnostics and treatment (recommendations by the Russian Medical Society for Arterial Hypertension Studies of the Russian Scientific Society of Cardiologists) ]. Sistemnye gipertenzii, 2010, no. 3, pp. 5-26 (in Russian).

9. Kaibysheva V.O., Kucheryavyi Yu.A., Trukhmanov A.S., Storonova O.A., Kon'kov M.Yu., Maev I.V., Ivashkin V.T. Results of multicenter observation study on application of international questionnaire GerdQ for diagnostics of gastroesophageal reflux disease. Rossiiskii zhurnal gastroenterologii, gepatologii, koloproktologii, 2013, vol. 23, no. 5, pp. 15-23 (in Russian).

10. Ivashkin V.T., Maev I.V., Trukhmanov A.S., Baranskaya E.K., Dronova O.B., Zairat'yants O.V., Saifutdinov R.G., Sheptulin A.A. Diagnostics and treatment of gastroesophageal reflux disease: clinical guidelines of the Russian gastroenterological association. Rossiiskii zhurnal gastroenterologii, gepatologii, koloproktologii, 2017, vol. 27, no. 4, pp. 75-95 (in Russian).

11. Timasheva Ya.R., Nasibullin T.R., Zakirova A.N., Mustafina O.E. Tumor necrosis factor alpha gene polymorphism in patients with essential hypertension. Kardiovaskulyarnaya terapiya i profilaktika, 2007, vol. 6, no. 6, pp. 5-9 (in Russian).

12. Li Y.Y. Tumor necrosis factor-alpha G308a gene polymorphism and essential hypertension: a meta-analysis involving 2244 participants. Plos One, 2012, vol. 7, no. 4, pp. e35408. DOI: 10.1371/ journal.pone. 0035408

13. Zhao Y., Li Z., Zhang L., Zhang Y., Yang Y., Tang Y., Fu P. The TNF-alpha -308G/A polymorphism is associated with type 2 diabetes mellitus: an updated meta-analysis. Molecular. Biology Reports., 2014, no. 41, pp. 73-83. DOI: 10.1007/s11033-013-2839-1

14. Sookoian S., Garcií S.I., Gianotti T.F., Dieuzeide G., González C.D., Pirola C.J. The G-308A promoter variant of the tumor necrosis factor-alpha gene is associated with hypertension in adolescents harboring the metabolic syndrome. American Journal of Hypertension, 2005, vol. 18, no. 10, pp. 1271-1275. DOI: $10.1016 /$ j.amjhyper.2005.04.014

15. Sbarsi I., Falcone C., Boiocchi C., Campo I., Zorzetto M., De Silvestri A., Cuccia M. Inflammation and atherosclerosis: the role of TNF and TNF receptors polymorphisms in coronary artery disease. International Journal of Immunopathology and Pharmacology, 2007, vol. 20, no. 1, pp. 145-154. DOI: $10.1177 / 039463200702000117$

16. Zhang P., Wu X., Li G., He Q., Dai H., Ai C., Shi J. Tumor necrosis factor-alpha gene polymorphisms and susceptibility to ischemic heart disease: A systematic review and meta-analysis. Medicine (Baltimore), 2017, vol. 95, no. 14, pp. e6569. DOI: 10.1097/MD.0000000000006569

17. Brazhnik V.A., Minushkina L.O., Averkova A.O. Polymorphism of TNF gene in acute coronary syndrome patients: data from the registries oracle I and oracle II. Rossiiskii kardiologicheskii zhurnal, 2018, vol. 23, no. 10, pp. 23-27 (in Russian).

18. Cheng H., Chang C.S., Wang H.J., Wang W.C. Interleukin $1 \beta$ and 10 polymorphisms influence erosive reflux esophagitis and gastritis in Taiwanese patients. Journal of Gastroenterology and Hepatology, 2010, vol. 25, no.8, pp. 1443-1451. DOI: 10.1111/j.1440-1746.2010.06310.x 
19. Yang F., Wei K., Qin Z., Shao C., Shu Y., Shen H. Association between TNF- $\alpha-308$ G/A polymorphism and esophageal cancer risk: An updated meta-analysis and trial sequential analysis. Journal of Cancer, 2019, vol. 10, no. 5, pp. 1086-1096. DOI: 10.7150/jca.29390

20. Haider S.H., Kwon S., Lam R. Predictive Biomarkers of Gastroesophageal Reflux Disease and Barrett's Esophagus in World Trade Center Exposed Firefighters: a 15 Year Longitudinal Study. Scientific Reports, 2018, no. 8, pp. 3106. DOI: 10.1038/s41598-018-21334-9

21. Peng D.F., Hu T.L., Soutto M., Belkhiri A., El-Rifai W. Loss of glutathione peroxidase 7 promotes TNF-alpha induced NF kappaB activation in Barrett's carcinogenesis. Carcinogenesis, 2014, no. 35, pp. 1620-1628. DOI: 10.1093/carcin/bgu083

22. Martens F.M., Rabelink T.J., Op't Roodt J., De Koning E.J.P., Visseren F.L.G. TNF-alpha induces endothelial dysfunction in diabetic adults, an effect reversible by the PPAR-gamma agonist pioglitazone. European Heart Journal, 2006, vol. 27, no. 13, pp. 1605-1609. DOI: 10.1093/eurheartj/ehl079

Khlynova O.V., Shishkina E.A., Sakhena V., Krivtsov A.V., Spasenkov G.N., Abgaryan N.I. TNF gene polymorphism as a risk factor that can cause arterial hypertension in patients suffering from gastroesophageal reflux disease. Health Risk Analysis, 2020, no. 1, pp. 126-132. DOI: 10.21668/health.risk/2020.1.14.eng

Received: 01.08.2020

Accepted: 09.02.2020

Published: 30.03 .2020 